\title{
BENEFIT-COST ANALYSIS OF MODESTO'S MUNICIPAL URBAN FOREST
}

\author{
by E. Gregory McPherson', James R. Simpson', Paula J. Peper ${ }^{1}$, and Qingfu Xiao²
}

\begin{abstract}
This study answers the question: Do the accrued benefits from Modesto's urban forest justify an annual municipal budget that exceeds $\$ 2$ million? Results indicate that the benefits residents obtain from Modesto's 91,179 public trees exceeded management costs by a factor of nearly 2 . In fiscal year 1997-1998, Modesto spent $\$ 2.6$ million for urban forestry ( $\$ 14.36 /$ resident, $\$ 28.77 /$ tree), and $74 \%$ of this amount was for mature tree care. Total annual benefits from Modesto's urban forest were $\$ 4.95$ million ( $\$ 27.12 /$ resident, $\$ 54.33 /$ tree). Net benefits for FY 1997 1998 were $\$ 2,329,900$ ( $\$ 12.76 /$ resident, $\$ 25.55 /$ tree) . Annual air-pollutant uptake was 154 metric tonnes (3.7 lb/tree), with an implied value of $\$ 1.48$ million ( $\$ 16$ / tree). Aesthetics and other benefits had an estimated value of $\$ 1.5$ million ( $\$ 17 /$ tree). Building shade and cooler summer temperatures attributed to street and park trees saved $110,133 \mathrm{MBtu}$, valued at $\$ 870,000(122 \mathrm{kWh} /$ tree, $\$ 10 /$ tree). Smaller benefits resulted from reductions in stormwater runoff $\left(292,000 \mathrm{~m}^{3}\right.$ or $845 \mathrm{gal} /$ tree, $\$ 616,000$ or $\$ 7 /$ tree) and atmospheric carbon dioxide $(13,900 \mathrm{t}$ or $336 \mathrm{lb} /$ tree, $\$ 460,000$ or $\$ 5 /$ tree). Due to the population's relatively even-aged structure and heavy reliance on mature Modesto ash for benefits, management strategies are needed that may reduce net benefits but increase diversity and stability.
\end{abstract}

Key Words. Urban forest valuation; economic analysis; natural resource economics.

The City of Modesto, California, manages over 90,000 trees along its streets and in its parks. Its Operations and Maintenance Department believes that the public's investment in stewardship of the municipal urban forest benefits the community. Located in northern California, Modesto has a population of 183,000 (California Department of Finance 1998) and needs to grow to maintain a vigorous local economy. However, the city's ability to grow is influenced by environmental constraints and competition with other regions in terms of quality of life. Research indicates that healthy city trees can mitigate impacts of development on air quality, climate, energy for heating and cooling buildings, and stormwater runoff. Healthy street trees increase real estate values, provide neighborhoods with a sense of place, and foster psychological well-being (Dwyer et al. 1992). Street and park trees are associated with other intangible benefits such as increased community attractiveness and recreational opportunities that make Modesto a more enjoyable place to work and play. Modesto's urban forest creates a setting that helps attract new businesses and residents.

In an era of dwindling public funds and rising expenditures, however, there is need to scrutinize expenditures often considered "nonessential," such as planting and management of the municipal forest.

Although the current program has demonstrated its efficiency, questions remain regarding the need for the level of service presently provided. Hence, the primary question this study asks is: Do the accrued benefits from Modesto's urban forest justify an annual municipal budget of over $\$ 2$ million? In answering this question, our purpose is to

- help decision makers assess and justify the degree of funding and type of management program appropriate for this city's urban forest

- provide critical baseline information for the evaluation of program cost efficiency, alternative pruning cycles, and alternative management structures

- highlight the relevance and relationship of Modesto's urban forest to local quality-of-life issues such as environmental health, economic development, and psychological well-being

- provide quantifiable data to assist in developing alternative funding sources through utility purveyors, air-quality districts, federal or state agencies, legislative initiatives, or local assessment fees.

\section{METHODS}

\section{Street Trees}

Modesto's street tree inventory database contains 75,649 trees and 184 species. We sampled 648 street trees belonging to 22 of the most abundant species in 
Modesto to 1) establish relations between tree age, size, leaf area, and biomass for important species, 2) estimate growth rates, and 3) collect other data on tree health, site conditions, and sidewalk damage. The number of trees belonging to the species sampled accounted for $92 \%$ of the entire street tree population. To obtain information spanning the life cycle of each species, we stratified the sample into 2 groups, young trees (planted 1970s-1990s) and old trees (planted before 1970). Approximately 30 randomly selected trees of each species were surveyed, 15 per group. We measured diameter at breast height (dbh), tree and bole height, crown radius, tree condition and location, severity of pruning, and site index. Replacement trees drawn randomly from the database were sampled when trees from the original sample population could not be located. When we suspected that planting dates were inaccurate, we took increment cores and/or contacted residents to determine actual planting dates.

Crown volume and leaf area were estimated from computer processing of digital images of tree crowns obtained using a Kodak Digital Science (TM) DC50 zoom camera. This photographic method involved computer processing of 2 images captured for each tree. The method has shown greater accuracy than other techniques ( $\pm 10 \%$ of actual leaf area) in estimating crown volume and leaf area of open-grown trees (Peper and McPherson 1998).

Nonlinear regression was used to fit a sigmoidshaped predictive model for $\mathrm{dbh}$ as a function of age for each species. Then, predictions for tree leaf area, crown diameter, and tree height were calculated as a function of dbh using nonlinear models (Peper and Mori, forthcoming).

To infer from the 22 species sampled to the remaining 162 species, called Other Street Trees, we categorized each species based on life form and mature size. Nine tree type categories were created, with 3 size classes for each of 3 life forms:

- Broadleaf deciduous: large ( $>15 \mathrm{~m}[50 \mathrm{ft}]$ ), medium (8-15 m [25-50 ft]), small $(<8 \mathrm{~m}$ [25 ft]) mature height

- Broadleaf evergreen: large, medium, small mature height

- Conifer: large, medium, small mature height
To obtain growth curves for Other Street Trees in each tree type category, we selected a typical species by comparing leaf area estimates for all species sampled. We had no species in our sample for conifer large and small types. Lacking empirical data, we increased and reduced dimensions of the Japanese black pine (Pinus thunbergiana) by $33 \%$ to derive dimensions for the large and small categories. These approximations are acceptable because trees in these categories comprise less than 1\% of the total street and park tree population.

\section{Park Trees}

There are 54 parks and 3 municipal golf courses in Modesto with trees that are managed by the city. Park trees have not been as thoroughly inventoried as street trees. Therefore, the city inventoried 23 parks to serve as a sample for this study. The number of trees in each tree type category were tallied for all 4 community parks, 12 of 42 neighborhood parks, 3 of 4 regional parks, 2 of 3 golf courses, and 2 of 4 undeveloped parks. Information on the area of all 57 parks was obtained and used as a basis for inferring tree numbers (trees/ha) from the sample to the population of parks by park type. This resulted in an estimate of the total number of park trees by tree type category. Lacking data on the age of park trees, we assumed that park and street trees were similarly distributed among age classes within each tree type (Gilstrap 1999).

\section{Annual Costs}

Expenditures reported by the Community Forestry Division during fiscal year 1997-1998 were used in this study. Tree-related expenses captured by other departments for sidewalk and curb repair, leaf cleanup, and claims were also included.

\section{Annual Benefits}

Annual benefits were estimated for 1998 using methods summarized below and described in detail in a technical report (McPherson et al. 1999). Growth rate information was used to "grow" the tree population for 1 year. Lacking detailed information on tree species planted and removed over the course of the year, we assumed that population numbers 
remained constant and accounted for annual benefits from the existing population. Our approach directly connected benefits with tree size variables such as dbh and leaf surface area. Many functional benefits of trees are related to leaf-atmosphere processes (e.g., interception, transpiration, photosynthesis); therefore, benefits increase as tree canopy cover and leaf surface area increase.

Prices were assigned to each benefit through direct estimation and implied valuation of benefits as environmental externalities. Findings from computer simulations were used to directly estimate energy savings (McPherson and Simpson 1999). Implied valuation was used to price society's willingness to pay for air quality and for the hydrologic and other benefits trees produce. For example, air-quality benefits were estimated using transaction costs that reflect the average market value of pollutant emission credits from 1994 through 1997 for the San Joaquin Valley Unified Air Pollution Control Management District. If a corporation is willing to pay $\$ 1 / \mathrm{kg}$ for a credit that will allow it to increase future emissions, then the air-pollution mitigation value of a tree that absorbs or intercepts $1 \mathrm{~kg}$ of air pollution should be $\$ 1$.

Energy savings. Changes in building energy use from tree shade were based on computer simulations that incorporated building, climate, and shading effects, following methods outlined by McPherson and Simpson (1999). Building characteristics (e.g., cooling and heating equipment saturations, floor area, number of stories, insulation, window area) were differentiated by a building's vintage, or age of construction: pre-1950, 1950 through 1980, and post1980. Typical meteorological year (TMY) weather data for Fresno were used. Shading effects were calculated for large, medium, and small trees, both deciduous and evergreen. The distribution of street trees with respect to buildings was based on analysis of aerial photos. It was assumed that street trees within $18 \mathrm{~m}(60 \mathrm{ft})$ of homes provided direct shade on walls and windows. In addition to localized shade effects from street trees, climate effects on reductions in energy use, air temperature, and wind. speed were estimated as a function of neighborhood canopy cover following McPherson and Simpson (1999). Peak summer air temperatures were reduced by $0.1^{\circ} \mathrm{C}\left(0.2^{\circ} \mathrm{F}\right)$ for each percentage increase in canopy cover. The dollar values of electrical energy savings (Kimball 1999) and natural gas savings (PG\&E 1998) were based on marginal electricity and natural gas prices of $\$ 0.079 / \mathrm{kWh}$ and $\$ 0.81 /$ therm, respectively.

Atmospheric carbon dioxide reductions. Reductions in building energy use result in reduced emissions of $\mathrm{CO}_{2}$. Emission reductions were calculated as the product of energy savings and $\mathrm{CO}_{2}$ emission factors for electricity and heating. Heating fuel is almost exclusively natural gas and electricity in the San Joaquin Valley, and the fuel mix for electrical generation in Modesto is approximately $60 \%$ hydroelectric, $25 \%$ natural gas, and $7 \%$ coal, with the remainder nuclear or renewable. Emissions factors for electrical generation ( $\mathrm{kg} /$ tree) were weighted by the appropriate fuel mix (Table 1 ).

Sequestration, the net rate of $\mathrm{CO}_{2}$ storage in above- and below-ground biomass over the course of 1 growing season, was calculated with tree growth data and biomass equations for urban trees (Pillsbury et al. 1998). Biomass equations for sweetgum (Liquidamber styraciflua) were used for deciduous trees, holly oak (Quercus ilex) for large broadleaf evergreens, southern magnolia (Magnolia grandiflora) for medium and small broadleaf evergreens, and Monterey pine (Pinus radiata) for all conifers. To calculate $\mathrm{CO}_{2}$ released through decomposition of dead woody biomass, we conservatively estimated that dead trees were removed and mulched in the year that death occurred and that $80 \%$ of their stored carbon was released to the atmosphere as $\mathrm{CO}_{2}$ in the same year. Annual tree mortality rates were supplied by the city and averaged $1.4 \%$ across all age classes.

Annual consumption of gasoline and diesel fuel over the course of a year by the Community Forestry Division was converted into $\mathrm{CO}_{2}$ equivalent emis-

Table 1. Emissions factors and transaction costs for $\mathrm{CO}_{2}$ and criteria air pollutants.

\begin{tabular}{lllc}
\hline & \multicolumn{3}{c}{ Emission factor } \\
\cline { 2 - 4 } & $\begin{array}{l}\text { Electricity } \\
\mathrm{kg} / \mathrm{MWh}\end{array}$ & $\begin{array}{l}\text { Natural gas } \\
\text { lb/MBtu }\end{array}$ & $\begin{array}{c}\text { Control } \\
\$ / \mathrm{kg}\end{array}$ \\
\hline $\mathrm{CO}_{2}$ & 181 & 75.7 & $0.033^{\mathrm{y}}$ \\
$\mathrm{NO}_{2}$ & 0.373 & 0.0797 & $11.03^{\mathrm{x}}$ \\
$\mathrm{PM}_{10}$ & 0.025 & 0.0049 & $6.98^{\mathrm{x}}$ \\
VOCs & 0.023 & 0.0035 & $6.13^{\mathrm{x}}$ \\
\hline
\end{tabular}

zU.S. Environmental Protection Agency 1995.

${ }^{y}$ California Energy Commission 1994 (\$30/ton).

${ }^{\times}$California EPA, 1998. 
sions. Approximately $395,089 \mathrm{~kg}$ (436 tons) were released due to tree program activities (McPherson and Simpson 1999). Carbon dioxide released from tree maintenance per $\mathrm{cm}$ dbh was estimated as $0.136 \mathrm{~kg}$ (0.76 lb).

Air-quality benefits. Reduced emissions of criteria air pollutants (volatile organic hydrocarbons [VOCs], nitrogen dioxide $\left[\mathrm{NO}_{2}\right]$ ), and particulate matter of $<10 \mu$ diameter $\left[\mathrm{PM}_{10}\right]$ ) from power plants and space-heating equipment were calculated using utility-specific emission factors for electricity and heating fuels (Table 1).

Trees also remove pollutants from the atmosphere. The hourly pollutant dry deposition per tree was expressed as the product of a deposition velocity $V_{d}=$ $1 /\left(R_{a}+R_{b}+R_{c}\right)$, a pollutant concentration $C$, a canopy projection area $\mathrm{CP}$, and a time step. Hourly deposition velocities for each pollutant were calculated using estimates for the resistances $R_{a}, R_{b}$, and $R_{c}$ for each hour throughout a "base year" (1991) as described by Scott et al. (1998). We assumed a 9-month in-leaf season for all trees, so interception results were conservative because evergreens will provide greater benefit than estimated because of their year-round foliage. A 50\% resuspension rate was applied to $\mathrm{PM}_{10}$ deposition. Hourly meteorological data for wind speed, solar radiation, and precipitation from California Department of Water Resources monitoring sites located in Modesto and Manteca were used as input data. Hourly concentrations for $\mathrm{NO}_{2}, \mathrm{O}_{3}$, and $\mathrm{PM}_{10}$ were obtained from the US EPA AIRS database for 1991 for a monitoring station located in Modesto. Transaction costs for $\mathrm{NO}_{2}$ were applied to ozone because ozone production is primarily $\mathrm{NO}_{\mathrm{x}}$ limited in the San Joaquin Valley (Table 1).

Stormwater runoff reductions. A numerical interception model accounted for rainfall intercepted by trees, as well as throughfall and stem flow (Xiao et al. 1998). The volume of water stored in tree crowns was calculated from crown projection areas (area under tree dripline), leaf area indexes (LAI, the ratio of leaf surface area to crown projection area), and water depths on canopy surfaces. Hourly meteorological and rainfall data for 1995 from the Modesto California Irrigation Management Information System were used as input. Annual precipitation during 1995 was 315 $\mathrm{mm}$ (12.3 in.), close to the average annual precipitation amount from 1988-1997 of $310 \mathrm{~mm}$ (12.1 in.).
Expenditures for Modesto's urban stormwater quality program and Fresno's flood control program were analyzed to estimate the implied value of rainfall intercepted. The City of Modesto spent approximately $\$ 350,000$ in FY 1997-1998 for its stormwater quality management program (Rivera 1998). Assuming that during a typical year $300 \mathrm{~mm}$ (12 in.) of rain falls on the city's 6,070 ha $(15,000 \mathrm{ac})$ of urbanized land and $40 \%$ of that becomes stormwater runoff, total annual runoff is about 7.4 million $\mathrm{m}^{3}(6,000 \mathrm{ac} \mathrm{ft})$. Hence, about $\$ 0.048$ is spent annually to improve water quality $/ \mathrm{m}^{3}$ ( $\left.\$ 0.0002 / \mathrm{gal}\right)$ of runoff.

Dry wells serve as Modesto's primary flood control measure. The impact of the urban forest on this system is difficult to determine, as were the costs associated with dry well installation, operation, and maintenance. Tree leaves and debris can clog dry wells and reduce their effectiveness. However, by delaying peak runoff, city trees can be an asset (Brusca 1998). Given these uncertainties, we rely on the costs for constructing and maintaining stormwater detention and retention basins in Fresno as an indication of willingness to pay for flood control. In Fresno, the average cost for constructing and maintaining a typical detention or retention basin is $\$ 300,000 / \mathrm{ha}$ ( $\$ 121,439 / \mathrm{ac}$ ) (Hofmann 1998). Assuming an annual maintenance cost of $\$ 2,000 /$ ha ( $\$ 800 / \mathrm{ac})$, the total cost for installation, operation, and maintenance for 20 years is $\$ 339,500 /$ ha $(\$ 137,400 / \mathrm{ac})$. There is a $50 \%$ probability that the 2 $\mathrm{m}(6-\mathrm{ft})$-deep basin will fill in any given year (designed to fill from $15 \mathrm{~cm}[6 \mathrm{in.}]$ of rain falling at $1.3 \mathrm{~cm} /$ hour intensity $[0.5 \mathrm{in} . / \mathrm{hr}$, 2-year return frequencyl). By filling 10 times over the 20 -year period, the cost of retention and detention is $\$ 2.03$ / $\mathrm{m}^{3}$ ( $\left.\$ 0.0077 / \mathrm{gal}\right)$. Because trees function similar to retention and detention basins by reducing overland flow and delaying the time of peak flow, interception was priced the same as retention and detention. Thus, the total annual price for stormwater runoff reduction summed to $\$ 2.07 / \mathrm{m}^{3}$ ( $\$ 0.008 / \mathrm{gal}$ ) due to flood control and water-quality protection.

Aesthetics and other benefits. Many benefits attributed to urban trees were difficult to translate into economic terms. Beautification, privacy, shade that increases human comfort, wildlife habitat, sense of place and well-being were difficult to price. However, the value of some of these benefits can be captured in the 
differences in sales prices of properties associated with trees. Anderson and Cordell (1988) found that each large, front-yard tree was associated with a $\$ 336$ increase in sales price ( $\$ 508$ in 1998 dollars when adjusted with the Consumer Price Index). We used this $\$ 508$ as an indicator of the additional value a Modesto resident would gain from the sale of residential property with a large street tree in front of the home. Based on growth data for a plane tree, such a tree is $14.2 \mathrm{~m}$ (48 ft) tall, with a 39-cm (15.3-in.) trunk diameter and $2,675 \mathrm{ft}^{2}\left(250 \mathrm{~m}^{2}\right)$ of leaf surface area.

To calculate the base value for a large street tree on private residential property, we treated street trees similar to front yard trees but recognized that they may be located adjacent to land with little value or resale potential. An analysis of street trees sampled from aerial photographs ( $8 \%$ of population) found that $15 \%$ were located adjacent to nonresidential or commercial land uses (Simpson, forthcoming). We assumed that $33 \%$ of these trees, or $5 \%$ of the entire street tree population, produced no benefits associated with property value increases. Although the impact of parks on real estate values has been reported (Hammer et al. 1974; Schroeder 1982), to our knowledge the on-site and external benefits of park trees alone have not been isolated (More et al. 1988). After reviewing the literature and recognizing an absence of data, we arbitrarily assumed park trees have 50\% of the impact on property sales prices as street trees. Given these assumptions, the typical large street and park trees increased property values by $\$ 1.93$ and $\$ 1.02 / \mathrm{m}^{2}$ of leaf surface area, respectively $(\$ 0.18$ and $\left.\$ 0.09 / \mathrm{ft}^{2}\right)$. To estimate annual benefits, we multiplied these values by the amount of leaf surface area added to the tree during 1 year of growth.

\section{Total Benefits}

To capture the total value of annual benefits $B$, each benefit was summed:

where

$$
\mathrm{B}=\mathrm{E}+\mathrm{AQ}+\mathrm{CO}_{2}+\mathrm{H}+\mathrm{O}
$$

$\mathrm{E}=$ price of net annual energy savings (cooling and heating)

$A Q=$ price of annual air-quality improvement (pollutant uptake and avoided power plant emissions)
$\mathrm{CO}_{2}=$ price of annual carbon dioxide reductions

$\mathrm{H}=$ price of annual stormwater runoff reductions

$\mathrm{O}=$ price of aesthetics and other benefits

\section{RESULTS \\ Tree Numbers and Species Composition}

There were approximately 91,179 public trees in Modesto, or 1 public tree for every 2 residents. Street trees accounted for $83 \%(75,629)$ of the total, while park trees comprised the remaining $17 \%(15,550)$. Compared to most California cities that care for less than 1 tree for every 4 residents (Bernhardt and Swiecki 1993), Modesto is relatively well-treed.

In Modesto, there were an average of $82 \mathrm{trees} / \mathrm{km}$ of street $(113 / \mathrm{mi})$. Average street tree spacing was $24 \mathrm{~m}(80 \mathrm{ft})$ on each side of city streets. The stocking level was $62 \%$ of full stocking ( $15 \mathrm{~m}$ [50 ft] spacing). Modesto's stocking level is very high compared to the mean stocking of $38 \%$ found for 22 U.S. street tree populations (McPherson and Rowntree 1989).

Park tree densities averaged 34 trees/ha (14/ac) and ranged from an average of 20/ha (8/ac) in undeveloped parks to $67 /$ ha $(27 / \mathrm{ac}$ ) in regional parks. Large- and small-statured trees were relatively more abundant in parks than in streets. Large-statured trees made up $77 \%$ of all park trees and $41 \%$ of all street trees, while small-statured trees accounted for $5 \%$ of all park trees and 3\% of all street trees. Mediumstatured trees were relatively less abundant in parks (18\%) than in streets (56\%). Compared to the street tree population, parks contained relatively more conifer/palms (25\% vs. $2 \%$ ) and broadleaf evergreens trees ( $16 \%$ vs. $5 \%$ ). Broadleaf deciduous trees were most abundant in both parks (59\%) and streets (93\%).

There were 184 different species of trees in the tree inventory database. The mean number of species recorded for 22 U.S. street tree populations was 53 (McPherson and Rowntree 1989). Compared to these cities, Modesto had a relatively rich assemblage of trees species along its streets.

Modesto ash (Fraxinus velutina 'Modesto') was the most common street tree species, with over 10,000 trees accounting for $14 \%$ of the population (Table 2). Chinese pistache (Pistacia chinensis and var. 'Pearl Street') and Callery pear cultivars (Pyrus calleryana 
cvs.) accounted for $13 \%$ and $11 \%$ of all street trees, respectively. These percentages surpass the customary guideline that no single species should exceed $10 \%$ of the population (Richards 1982/83; Miller 1997) but may be misleading from a genetic diversity perspective. The ornamental pear population consisted of 9 distinct varieties, and pistache are typically propagated from seed and thus inherently contain more genetic diversity than found in a specific clone or cultivar. Other important species include zelkova (Zelkova serrata, 7\%), Chinese hackberry (Celtis sinensis, 6\%), ginkgo (Ginkgo biloba, 5\%), honeylocust varieties (Gleditsia triacanthos var, 4\%), sweetgum (4\%), and several varieties of ash (Fraxinus) such as Hesse (F. excelsior 'Hesse', 5\%), Raywood (F. oxycarpa 'Raywood', 5\%), Marshall (F. pennsylvanica 'Marshall', $5 \%$ ), and Moraine (F. holotricha 'Moraine', 4\%).

\section{Dominance and Age Structure}

Modesto ash accounted for $42 \%$ of all street tree basal area (or trunk area), $36 \%$ of all leaf area, and $26 \%$ of all canopy cover (Table 2). Silver maple (Acer saccharinum) and Chinese hackberry were relatively more important than their numbers indicated because of their age and size. Some species were very abundant but relatively unimportant. For example, Callery pear's small mature size and the relatively recent planting of many Hesse ash (3,075 in the 5-year age class) explain why these species accounted for relatively small percentages of total basal area, leaf area, and canopy cover, despite being among the most predominant street trees.

The age structure for all public trees in Modesto had a relatively even distribution of trees among age classes (Figure 1). Trees less than 10 years old accounted for only $20 \%$ of the population compared to the "ideal" of $40 \%$. The difference may be due to higher than normal survival rates in Modesto and limited availability of new planting sites. The pattern suggests that a large number of trees were planted from 1960 to 1985 to fill out Modesto's urban forest.

Age curves for different tree species help explain their relative dominance and suggest how tree management needs may change as these species grow older. Around $85 \%$ of all Modesto ash were more than 45 years old. These trees have provided substantial benefits over a long period of time and were gradually being replaced by species less susceptible to anthracnose and other pest or disease problems. Nearly $60 \%$ of all the sycamore/plane (Platanus spp.) were planted over 55 years ago, but unlike the Modesto ash, there has been a resurgence in planting of this species. Recent plantings account for $30 \%$ of all sycamore/plane. Over $50 \%$ of all Callery pears were planted about 15 years ago, and the species continues to be planted in large numbers ( $40 \%$ were 5 years old). Pistache trees appear to have been planted heavily 20 to 40 years ago, and again within the past 10 years.

Table 2. Structural features of Modesto's street trees.

\begin{tabular}{|c|c|c|c|c|c|c|c|c|}
\hline & \multicolumn{2}{|c|}{ Tree numbers } & \multicolumn{2}{|c|}{ Basal area } & \multicolumn{2}{|c|}{ Leaf area } & \multicolumn{2}{|c|}{ Canopy cover } \\
\hline & No. & $\%$ total & $\mathrm{m}^{2}$ & $\%$ total & $1,000 \mathrm{~m}^{2}$ & $\%$ total & $1,000 \mathrm{~m}^{2}$ & $\%$ total \\
\hline Modesto ash & 10,592 & 14.0 & 310 & 32.8 & 4,999 & 28.4 & 1,446 & 24.1 \\
\hline Chinese pistache & 9,709 & 12.8 & 55 & 5.8 & 1,557 & 8.8 & 692 & 11.5 \\
\hline Callery pear & 8,019 & 10.6 & 31 & 3.3 & 718 & 4.1 & 287 & 4.8 \\
\hline Zelkova & 5,046 & 6.7 & 34 & 3.6 & 831 & 4.7 & 380 & 6.3 \\
\hline Chinese hackberry & 4,662 & 6.2 & 66 & 7.0 & 1,610 & 9.1 & 520 & 8.7 \\
\hline Hesse ash & 4,082 & 5.4 & 9 & 1.0 & 173 & 1.0 & 78 & 1.3 \\
\hline Raywood ash & 3,953 & 5.2 & 41 & 4.3 & 869 & 4.9 & 256 & 4.3 \\
\hline Marshall ash & 3,464 & 4.6 & 15 & 1.6 & 488 & 2.8 & 206 & 3.4 \\
\hline Ginkgo & 3,434 & 4.5 & 15 & 1.6 & 285 & 1.6 & 92 & 1.5 \\
\hline Sweetgum & 2,956 & 3.9 & 26 & 2.7 & 626 & 3.6 & 138 & 2.3 \\
\hline Moraine ash & 2,921 & 3.9 & 68 & 7.2 & 1,094 & 6.2 & 317 & 5.3 \\
\hline Honeylocust & 2,916 & 3.9 & 49 & 5.2 & 901 & 5.1 & 402 & 6.7 \\
\hline Sycamore/plane & 2,039 & 2.7 & 33 & 3.5 & 658 & 3.7 & 245 & 4.1 \\
\hline Silver maple & 1,254 & 1.7 & 83 & 8.7 & 1,147 & 6.5 & 276 & 4.6 \\
\hline Other street trees & 10,582 & 14.0 & 110 & 11.6 & 1,668 & 9.5 & 663 & 11.0 \\
\hline Total street trees & 75,629 & 100.0 & 947 & 100.0 & 17,624 & 100.0 & 5,997 & 100.0 \\
\hline
\end{tabular}




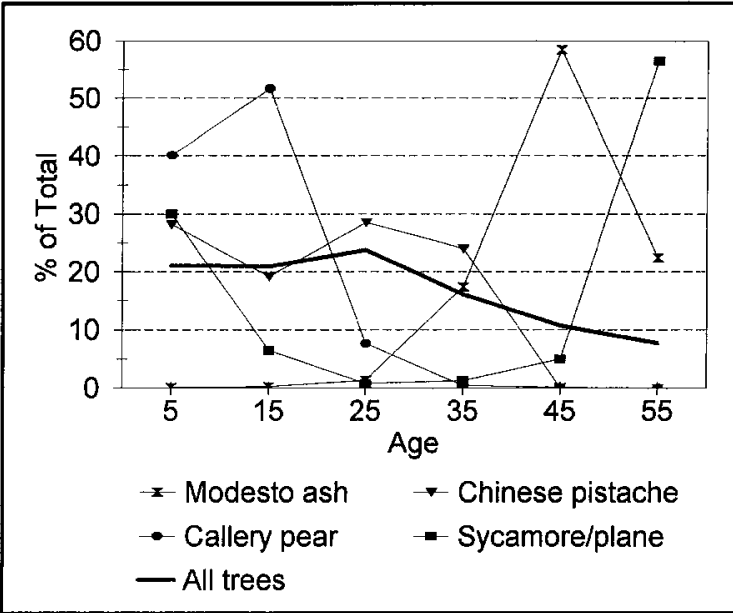

Figure 1. The age structure for the category All Street Trees showed a relatively low percentage of young trees (e.g., Callery pear) to replace an abundance of older trees, such as Modesto ash and sycamore/plane.

\section{Tree Canopy Cover}

Tree canopy cover for the entire city was $31 \%$,based on a Normalized Difference Vegetation Index analysis of Landsat 5 Thematic Mapper data (30-m resolution). Street and park tree canopy covered 756 ha $(1,866 \mathrm{ac})$, or $8.3 \%$ of the entire city $(9,065$ ha or 35 $\mathrm{mi}^{2}$ ). Street trees provided $80 \%$ and park trees $20 \%$ of the total canopy cover from public trees. Modesto's street trees shaded approximately $30 \%$ of all street paving, assuming that $50 \%$ of all street tree canopy cover shaded street surfaces, an average

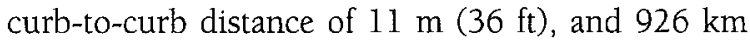
(525 miles) of streets.

\section{Condition of Existing Trees}

Overall, the municipal urban forest appeared healthy. Eighteen percent of the trees were in excellent condition, $58 \%$ were in good condition, and $21 \%$ were in fair condition. Only $3 \%$ of the street trees were in poor condition, dying, or dead. Species in the best condition on average were ginkgo, crapemyrtle (Lagerstroemia indica), Chinese hackberry, and zelkova. These species are widely adapted to growing conditions throughout the city. Ginkgo and zelkova continue to be planted in large numbers. Chinese hackberry has shown high susceptibility to a root rot disease and is no longer planted.
Species with the lowest condition rating were Moraine ash, cherry plum (Prunus cerasifera), holly oak (Quercus ilex), honeylocust, and Modesto ash. Very few of these species are planted today.

\section{Expenditures}

Tree establishment activities consumed $12 \%$ of the tree program's budget, or $\$ 271,000$ (Table 3). Tree planting $(\$ 167,000,2,000$ trees) was the single largest cost category, followed by pruning, irrigation of young trees, and basin repairs (total to $\$ 90,000$ ). Approximately $\$ 14,000$ was spent operating the nursery. Mature tree care comprised 74\% (\$1.67 million) of the tree program's budget, and inspection and pruning accounted for $69 \%$ of this amount ( $\$ 1.1$ million). The Community Forestry Division removed 1,300 trees at a cost of $\$ 343,000$. Clean-up after storms cost $\$ 5,000$. To protect sidewalks and private property from damage, the tree program spent approximately $\$ 85,000$ for root pruning and installation of root barriers. Approximately $\$ 68,000$ was spent on Integrated Pest Management to detect when populations of insects and disease were becoming a problem and to control their numbers in a safe and cost effective manner. Administration costs accounted for $14 \%(\$ 316,000)$ of the budget and included salaries and benefits of supervisory staff (4) and clerical assistants (2).

During FY 1997-1998, a total of $\$ 297,586$ was spent on sidewalk and curb repair (Marino 1999). Expenditures for leaf clean-up were estimated as $\$ 106,426$. Although the Community Forestry Division has an excellent service record, damage occasionally occurs to private property due to limb failure, inaccurately located irrigation or sewer lines, or conflicting landscaping. Expenditures for property claims averaged $\$ 26,000$ annually (Eubank 1995). The average annual payment for all tree-related trip-and-fall claims was $\$ 42,000$ (Lagarbo and Brusca 1996). Total claims expenditures were $\$ 68,000$ (Table 3).

\section{Revenues}

Payment in the form of service credits of $\$ 10,132$ was received for tree planting and care services (Table 3). Fees collected from developers to cover the cost of planting trees in new subdivisions totaled $\$ 46,000$. Revenue totaling $\$ 7,000$ was received from the Modesto Irrigation District for line-clearance 
work. The Community Forestry Division received revenue for these services totaling $\$ 63,132$.

\section{Annual Costs}

Total fiscal year 1997-1998 expenditures were $\$ 2,686,516$, and revenues totaled $\$ 63,132$ (Table 3). Net expenditures totaled $\$ 2,623,384$ ( $\$ 14.36 /$ resident, $\$ 28.77 /$ tree). This amount represents $2 \%$ of the city's total operating budget ( $\$ 123.1$ million). Survey results suggest that annual expenditures by the Community Forestry Division were about $7 \%$ greater than the statewide average (Bernhardt and Swiecki 1993). Keeping old trees healthy, perpetuating the forest through planting, and providing a safe, healthful, and attractive environment for the public comes with a price.

\section{Annual Benefits}

Energy savings. Electricity saved annually from both shading and climate effects was $12,681 \mathrm{MWh}$, for a total retail savings of nearly $\$ 1,002,000$. Savings per tree for park trees averaged $\$ 10.88$, almost as much as the $\$ 11.01 /$ tree amount for street trees. Park trees were larger on average than street trees, and their climate benefits almost equaled the combined shade and climate benefits of street trees. Airtemperature reductions accounted for approximately $60 \%$ of cooling savings. Street and park trees produced a small increase in heating costs because increased heating due to winter tree shade was slightly greater than savings from wind-speed reductions (a climate effect). The total increased cost for natural gas was $\$ 1,233$ (152 MBtu). Net energy savings (Table 4) were over $126,000 \mathrm{MBtu}$, valued at $\$ 1 \mathrm{mil}$ lion. Average annual savings were $\$ 10.97 /$ tree, and as much as $\$ 20$ for large-growing tree species.

Atmospheric $\mathrm{CO}_{2}$ reductions. Over 2,600 metric tonnes ( $t$, or $1,000 \mathrm{~kg})\left(2,800\right.$ short tons) of $\mathrm{CO}_{2}$ emissions were avoided annually as a result of energy saved from reduced space heating and air conditioning. This savings was valued at over $\$ 87,000$, averaging $\$ 0.95 /$ tree, and as high as $\$ 1.70$ /tree. Sequestration less releases due to decomposition and maintenance (net sequestration) resulted in total savings of nearly $11,000 \mathrm{t}$ (12,000 tons) of $\mathrm{CO}_{2}$, with an implied value of over $\$ 360,000$. Net $\mathrm{CO}_{2}$ reduction, the sum of avoided and net sequestration, was $13,591 \mathrm{t}$ (15,000 tons), with a value of nearly
Table 3. FY 1997-1998 expenditures and revenues for Modesto, California.

Expenditure

Tree establishment

Planting

$\$ 167,062$

Irrigation/pruning

75,136

Basin repairs

15,200

Nursery

Subtotal

13,693

$\$ 271,090$

Mature tree care

Pruning

Tree and stump removal

$\$ 1,127,117$

342,896

85,208

67,747

IPM

$\frac{4,874}{\$ 1,627,842}$

Storm clean-up

Subtotal

Administration

Supervisory and clerical staff

$\$ 315,572$

Other expenditures

Sidewalk and curb repair

Leaf clean-up

$\$ 297,586$

106,426

Claims

Total expenditures

68,000

$\$ 2,686,516$

Revenue

Service credits

Development fees

Contracts

Total revenue

$\$ 10,132$

46,000

7,000

$\$ 63,132$

Net expenditures

$\$ 2,623,384$

$\$ 450,000$ (Table 4 ). The average benefit was $\$ 4.93$ / tree, with a maximum of $\$ 14 /$ tree. Modesto ash (19\%), Moraine ash (12\%), hackberry (7\%), and honeylocust $(7 \%)$ were responsible for the largest percentages of net atmospheric $\mathrm{CO}_{2}$ reductions by street tree species. Net sequestration was approximately 4 times greater than avoided $\mathrm{CO}_{2}$ emissions. This result was largely due to the small proportion of fossil-fueled electricity and a large proportion of hydroelectric power.

Air-quality benefits. Avoided emission of $\mathrm{NO}_{2}$, $\mathrm{PM}_{10}$ and VOCs due to energy saved from reduced space heating and air conditioning were small, totaling $6.5 \mathrm{t}$ (7.2 tons), valued at $\$ 68,000$. This result reflects the small proportion of fossil-fuel fired (coal or natural gas) electric generation plants in Modesto's resource mix and the relatively small emissions factors for these pollutants. Pollutant deposition and particulate inter- 
Table 4. The value of annual benefits from Modesto's municipal forest.

\begin{tabular}{llrr}
\hline Benefit category & Total \$ & $\begin{array}{l}\text { \% of } \\
\text { total benefit }\end{array}$ & $\begin{array}{l}\text { Avg } \\
\$ / \text { tree }\end{array}$ \\
\hline Environmental & & & \\
$\quad$ Energy & $1,000,560$ & 20.2 & 10.97 \\
$\mathrm{CO}_{2}$ & 449,445 & 9.1 & 4.93 \\
$\quad$ Air quality & $1,442,036$ & 29.1 & 15.82 \\
$\quad$ Stormwater & 616,139 & 12.4 & 6.76 \\
Environmental subtotal & $3,508,180$ & 70.7 & 38.48 \\
Aesthetic and other & $1,455,636$ & 29.3 & 15.96 \\
Total benefits & $\mathbf{4 , 9 6 3 , 8 1 6}$ & $\mathbf{1 0 0 . 0}$ & $\mathbf{5 4 . 4 4}$ \\
\hline
\end{tabular}

ception totaled $143 \mathrm{t}$ (157 tons). The total value of this benefit was nearly $\$ 1.4$ million. Ozone, $\mathrm{NO}_{2}$ and $\mathrm{PM}_{10}$ uptake accounted for $\$ 746,000(54 \%), \$ 356,000$ $(26 \%)$ and $\$ 272,000(20 \%)$ of the savings, respectively. Total benefits (avoided emissions plus uptake) were approximately 150 t (165 tons), valued at over $\$ 1.4$ million (Table 4). Savings averaged almost \$16/tree, and were as large as $\$ 36 /$ tree. Net air-quality savings were primarily due to pollutant uptake, since the amount of avoided pollutants was small.

Not included in this analysis was the cost associated with increased ozone formation due to the emission of biogenic volatile organic compounds (BVOCs) from trees, or the benefit from lowering summer air temperatures, thereby reducing hydrocarbon emissions from anthropogenic and biogenic sources. A review of simulation results from Los Angeles and Sacramento indicates that ozone reduction benefits of tree planting with "low-emitting" species such as Modesto ash exceed costs associated with their BVOC emissions (Taha 1996; Benjamin and Winer 1998; McPherson et al. 1998).

Stormwater runoff reductions. Modesto's street and park trees were estimated to reduce annual runoff by around 292 million $\mathrm{m}^{3}(102,943 \mathrm{Ccf})$ with an implied value of $\$ 616,000$ (Table 4 ). On average, each tree reduced stormwater runoff by $3.2 \mathrm{~m}^{3}$ ( $845 \mathrm{gal}$ ) annually, and the value of this benefit was $\$ 6.76$. Although park trees comprised only $17 \%$ of the total tree population, they accounted for $32 \%$ of this hydrologic benefit and the average per-tree benefit was $\$ 12.62$. The relatively large size and high proportion of park trees with evergreen foliage compared to street trees explains this finding. Broadleaf evergreens and conifers were predicted to intercept more rainfall than deciduous trees because of the winter rainfall pattern.
Aesthetics and other benefits. The estimated total annual value of aesthetics and other benefits was nearly $\$ 1.5$ million (Table 4 ). Street trees were responsible for $95 \%$ of this benefit because they were assumed to have greater impact on aesthetics and property values than park trees. The 5 most abundant street tree species accounted for $45 \%$ of the total benefit from street trees. Tree species adding the largest amount of leaf area over the course of a year produced the highest average annual benefit: silver maple (\$49), honeylocust (\$34), Moraine ash (\$33), Chinese hackberry $(\$ 28)$, and sweet gum $(\$ 28)$.

\section{Total Benefits}

Total benefits produced during 1998 by Modesto's street and park trees were estimated to have a value of nearly $\$ 5$ million (Table 4), about $\$ 27 /$ resident. The average annual benefit per tree was $\$ 54$ ( $\$ 54$ / street tree and $\$ 57 /$ park tree). Street trees produced benefits valued at $\$ 4$ million, while park tree benefits were valued at $\$ 890,000$ and represented $18 \%$ of total benefits. Urban forest impacts on aesthetics and other benefits accounted for $29 \%$ of total benefits ( $\$ 16 /$ tree) (Figure 2). Air-quality benefits were of similar magnitude (29\% of total benefits, $\$ 16 /$ tree). Benefits associated with energy savings represented 20\% ( $\$ 11 /$ tree) of total benefits. Storm-water runoff reductions and atmospheric $\mathrm{CO}_{2}$ reductions accounted for $12 \%(\$ 7 /$ tree $)$ and $9 \%(\$ 5 /$ tree $)$ of estimated total annual benefits, respectively.

Modesto ash comprised 14\% of all street trees and accounted for $22 \%$ of all street tree benefits by virtue of their size and numbers (Figure 2). Chinese pistache (9\%), Chinese hackberry (9\%), and Moraine ash (6\%) were also important producers of benefits.

Trees less than 20 years old made up $40 \%$ of the tree population but were responsible for only $23 \%$ of total benefits. The magnitude of future benefits depends on the extent to which these young trees grow older and larger. Callery pear cultivars accounted for $18 \%$ of the total $\$ 1.2$ million in benefits from young trees. Because ornamental pear trees do not grow to be very large, their potential to produce future benefits is limited. Other species that accounted for greater than $10 \%$ of benefits from young street trees were Raywood ash, zelkova, and Chinese pistache.

Mature trees ( 20 to 40 years old) comprised $40 \%$ of the population and accounted for $46 \%$ of total benefits 
(\$2.3 million). Moraine ash, Chinese pistache, and Chinese hackberry each produced benefits in excess of $10 \%$ of total benefits produced by all 20 - to 40 -year-old street trees. Benefits were more evenly distributed among species in this age class compared to the young tree age class. The continued health and longevity of mature trees is vital to ensuring benefits in the years ahead. Unfortunately, honeylocust, Chinese hackberry, and Moraine ash are quite susceptible to disease and pest problems that threaten their health and longevity. Also, sweetgum is another important species that has proven to become less serviceable with age due to shallow rooting and fruit drop.

Old trees (more than 40 years old) were $20 \%$ of the population but produced $32 \%$ of all benefits $(\$ 1.6$ million). Their average annual per tree benefit was $\$ 96$ (Figure 3). Modesto ash alone accounted for $47 \%(\$ 753,000)$ of total annual

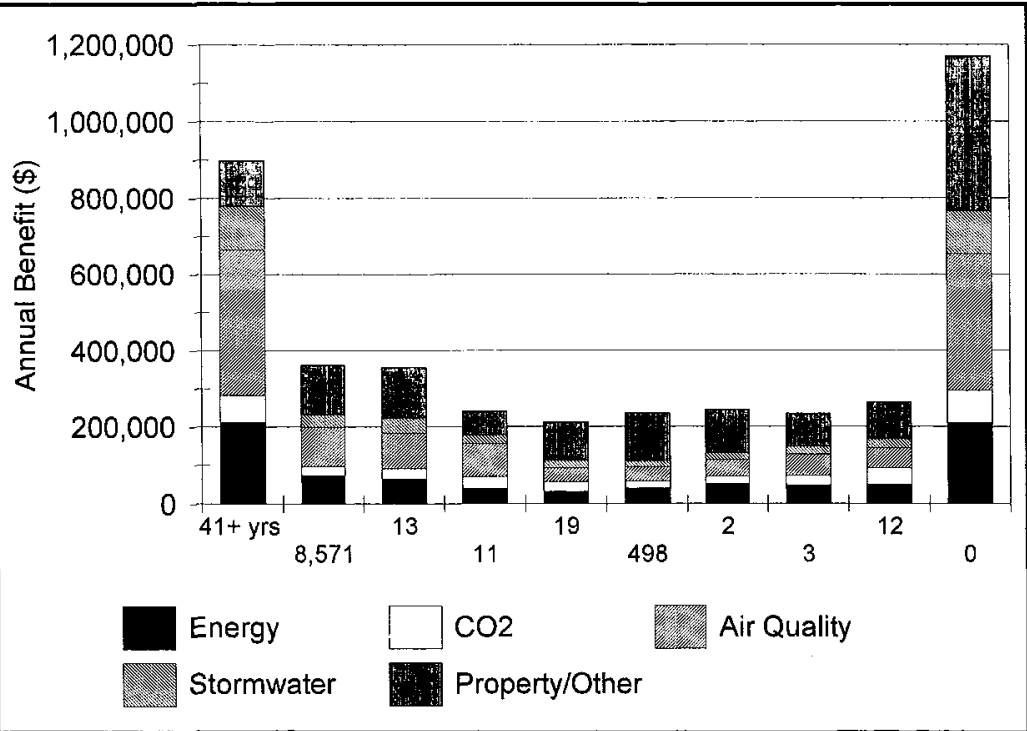

Figure 2. Modesto ash accounted for $14 \%$ of the street tree population and produced $22 \%$ of total benefits. Because of their relatively old age and large size, they make a substantial contribution to airquality improvements. Also, Modesto ash is a low emitter of BVOCs (Benjamin and Winer 1998). Unlike air-quality benefits that reflect the total amount of leaf area, aesthetic and other benefits depend on the rate that leaf area is added and are relatively more important than air-quality benefits for more recently planted species such as the Callery pear. benefits from old street trees, while silver maple and sycamore/plane contributed $15 \%$ and $6 \%$, respectively. Relying on these few species for such a large portion of total benefits is risky. Commonly, relatively few species come to dominate urban forests by virtue of their ability to survive the tests of time. Modesto ash has proven to be a serviceable tree, but older trees are now afflicted with anthracnose, mistletoe, and limb breakage problems. Intensive inspection and maintenance have been necessary to ensure that these and other problems do not jeopardize tree health, public safety, and the sizable benefits that these trees produce.

\section{Net Benefits and Benefit-Cost Ratio}

Total fiscal benefits of $\$ 4,964,000$, less net expenditures of $\$ 2,623,000$, resulted in a net annual benefit of $\$ 2,340,000$. Average annual net benefits per resident and per tree were $\$ 13$ and $\$ 26$, respectively. The benefit-cost ratio (BCR) was 1.89 , meaning that for each $\$ 1$ in net expenditures for urban forest management, benefits valued at $\$ 1.89$ were returned to the residents of Modesto.

\section{Uncertainty and Limitations}

We have greater certainty in our estimates of expenditures than benefits. Estimates of annual benefits are related to annual growth increments, and the variability associated with growth parameters increases with tree age. Thus, estimation error is likely to be greater for species with a preponderance of older trees, such as Modesto ash and silver maple, than for species with more younger trees.

Uncertainty is greatest in estimating the amount of air-pollutant uptake by trees, the value of stormwater runoff reductions, and the value of aesthetics and other benefits. Although our estimates of air-pollutant uptake were in good agreement with results from urban forestry studies for Chicago and Sacramento, our ability to accurately estimate the extent to which shade trees produce air-quality benefits is impaired by uncertainties regarding rates of pollutant deposition. We used canopy resistance values for rural forests because data were lacking for urban trees. We expect urban trees might have lower canopy resistance values than trees in rural forests 


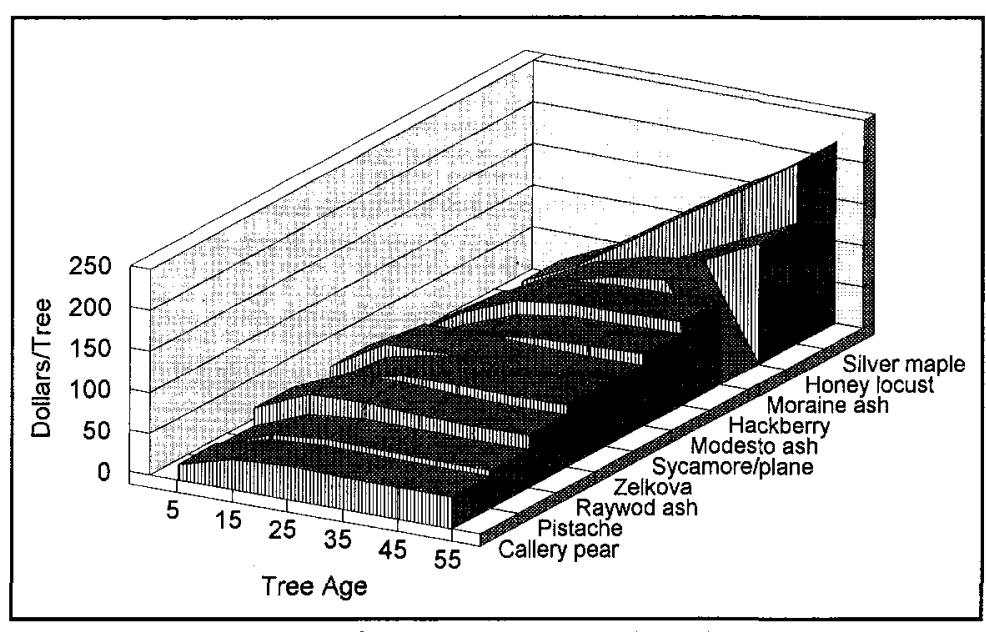

Figure 3. Annual benefits per tree varied with tree species, depending on size and growth rate. On average, benefits increased from $\$ 20$ for 5-year-old trees to $\$ 100$ for trees 5 years and older. For young trees, rapid-growing species such as sycamore/plane and Raywood ash produced the greatest annual benefits per tree. For old trees, species such as silver maple, honeylocust, Moraine ash, and hackberry produced the greatest benefits because they continue growing long after planting.

due to lower levels of water stress and higher gas exchange rates. If this is the case, pollutant uptake rates will be greater than we estimate here. Although we have used the best information currently available, application of new research results or different modeling techniques could alter these findings. Net benefits are sensitive to assumptions regarding pollutant uptake rates because air-quality benefits represented $30 \%$ of total benefits.

Most of the stormwater benefit was associated with flood control and, lacking data for Modesto, we valued this benefit using control costs for stormwater retention and detention basins. Because such basins were not used in Modesto, it could be argued that this is an inaccurate estimate and no flood control benefits were realized. If this is the case, total benefits are reduced $\$ 616,139$ to $\$ 4.3$ million, net benefits drop to $\$ 1.7$ million, and the BCR drops to 1.66 .

We also have a poorer understanding of the effects of climate modification on energy savings compared to shading effects. A more liberal interpretation of the relevant literature would lead to a doubling of airtemperature reductions, which were conservatively based on reductions of $0.1^{\circ} \mathrm{C}\left(0.2^{\circ} \mathrm{F}\right)$, for each percentage increase in canopy cover. Such an interpretation would increase electricity savings from $\$ 1$ million to about to $\$ 1.7$ million. This, increased savings from ancillary affects on avoided $\mathrm{CO}_{2}$ and other pollutant emissions from power plants would increase the BCR from 1.89 to 2.20 .

Estimating the value of aesthetics and other benefits is open to debate because little research has resolved this question. We assumed a 50\% reduction in benefit for a park tree compared to an identical street tree. Park trees directly impact the sales prices of relatively few properties compared to street trees, but park and golf course trees contribute to recreational settings used by large numbers of residents. Many residents enjoy the intangible "other benefits" provided by park trees. Given that the total value of aesthetic and other benefits from park trees was only $\$ 86,000$, reducing or increasing the park tree reduction factor would not substantially alter results of this analysis.

In this analysis, expenditures associated with tree removal were included. However, benefits were also included, as if the trees were removed at year end. If all 1,300 trees ( $1.4 \%$ of tree population) were removed at the beginning of the year, total leaf surface area and canopy cover would be reduced by $1.6 \%$ and $1.8 \%$, respectively. Assuming a corresponding $1.8 \%$ reduction in benefits results in an $\$ 88,000$ reduction in total benefits. These assumptions regarding tree mortality do not have a marked influence on the outcome of this analysis.

\section{CONCLUSIONS}

Over the years, Modesto has invested millions in its municipal forest. Citizens are now receiving a relatively large return on that investment. Continued investment in management is critical to sustaining these benefits. Although over 180 different species of trees have been planted along streets, Modesto ash planted 30 to 60 years ago are the dominant trees. They account for $14 \%$ of all street trees, but produce $22 \%$ of all benefits. Chinese pistache and Callery pear are other important street tree species by virtue of their numbers. The Modesto tree population has a 
relatively even-age structure, indicating fewer young, replacement trees and more old, overmature trees than is considered ideal. Given this age structure, it is not surprising that expenditures for mature tree care comprise $74 \%$ of the Community Forestry Division's expenditures. Substantial funds are spent addressing other mature tree-related issues such as sidewalk repair, root pruning, and trip-and-fall claims. Because of the existing forest's even-aged structure and the reliance on benefits from Modesto ash, spending less on management at this time could jeopardize the future stream of net benefits.

Modesto's investment in urban forestry is providing tangible air quality, flood control, energy conservation, and $\mathrm{CO}_{2}$ reduction benefits. The sources of these benefits suggest potential new partners in urban forest management. The local air quality and stormwater management districts, electric utility, and industry could view Modesto's urban forest as an asset to their programs. As air-pollution trading markets develop, there is potential for the city to claim credits for these benefits. Urban forestry credits could be applied against municipal emissions or sold to local emitters. Money obtained from the sale of credits could help finance the tree program. Pollution trading markets exist for several criteria pollutants $\left(\mathrm{PM}_{10}\right.$, $\mathrm{NO}_{2}$, VOCs) and have been proposed for $\mathrm{CO}_{2}$.

Looking toward the future, it may not be possible to maintain the high level of net benefits produced today by Modesto's municipal forest while at the same time increasing its stability. Creating a more stable forest may be a more appropriate goal than maximizing net benefits if it reduces the risk of catastrophic loss and lowers management costs on a per-tree basis. Achieving a more stable forest will challenge management because of the forest's current structure. At least 3 factors are significant:

- Modesto ash will be gradually replaced during the next 20 years, resulting in a substantial short-term reduction of canopy cover and associated benefits.

- Many of the mature trees planted 20 to 40 years ago that should be moving into the old-tree class and replacing benefits lost by removal of Modesto ash may not do this. Several of the predominant species in this age class (i.e., honeylocust, Chinese hackberry, Moraine ash, and sweetgum) appear to have relatively short useful life spans and are not likely to survive 20 to 40 more years. Also, there is danger of relying too heavily on Chinese pistache, which already accounts for $18 \%$ of all street trees in the 20 - to 40-year age class. If in fact these problematic species do require replacement coincident with replacement of Modesto ash over the next 20 years, there will be a substantial loss in tree canopy cover. Budgets for pruning of mature trees will decrease, while expenditures for tree removal and planting will increase. Filling vacant planting sites is an opportunity to create a more balanced and stable forest by increasing the number of young trees.

- Forest benefits that our children's children will realize depend on the survival and growth of young trees planted within the last 20 years. Unfortunately, only $12 \%$ of all trees less than 20 years old have the potential to grow to be large statured (>15 m [50 ft]), 22\% of these are Callery pear cultivars, and 13\% are Chinese pistache. As these medium-statured trees mature, they will not fill the void left by the larger-statured trees they replace. Furthermore, future benefits are likely to be minimal from the relatively short-lived Callery pear. Additional fiscal resources will be needed in the short-term for replacement of pears and other young trees with relatively short useful life spans. The implication here is that the future forest will consist of relatively fewer large-statured trees. When the 40-year stream of future costs and benefits is considered, large trees can provide substantially higher net benefit than small trees, even though they are more expensive to maintain (McPherson et al. 1999).

The Community Forestry Division is taking advantage of the opportunity it has to create a more stable urban forest and increase net benefits. Their nursery makes it possible to grow and evaluate the success of new introductions such as American persimmon (Diospyros virginiana), Autumn Purple ash (Fraxinus americana 'Autumn Purple'), Urbanite ash (Fraxinus pennsylvanica 'Urbanite'), and catalpa (Catalpa speciosa). Staff are working with researchers and other partners to identify strategies for mitigating sidewalk repair costs, including breeding of trees with vertical rooting patterns. 
Modesto's municipal urban forest reflects the values, lifestyles, preferences, and aspirations of current and past residents. It is a dynamic legacy, on one hand dominated by trees planted over 40 years ago and at the same time constantly changing as new trees are planted and others mature. Modesto's urban forest is in an era of transition. Planning and managing the transition from a relatively fragile forest to one that is more diverse and stable will require careful thinking, powerful analysis tools, and new partners.

\section{LITERATURE CITED}

Anderson, L.M., and H.K. Cordell. 1988. Influence of trees on residential property values in Athens, Georgia (U.S.A.): A survey based on actual sales prices. Landscape Urban Plann. 15:153-164.

Benjamin, M.T., and A.M. Winer. 1998. Estimating the ozone-forming potential of urban trees and shrubs. Atmos. Environ. 32:53-68.

Bernhardt, E., and T.J. Swiecki. 1993. The state of urban forestry in California: Results of the 1992 California urban forest survey. California Department of Forestry and Fire Protection. Sacramento, CA.

Brusca, J. 1998. Personal communication. Streets Superintendent, City of Modesto, CA.

California Department of Finance. 1998. City/County Population and Housing Estimates, 1990-1998. State of California, Department of Finance, Sacramento, CA.

California Energy Commission. 1994. Electricity Report. State of California, Energy Commission, Sacramento, CA.

California EPA. 1998. Emission Reduction Offset Transaction Cost Summary Report for 1997. State of California, Environmental Protection Agency, Air Resources Board, Sacramento, CA.

Dwyer, J.F, E.G. McPherson, H.W. Schroeder, and R.A. Rowntree. 1992. Assessing the benefits and costs of the urban forest. J. Arboric. 18:227-234.

Eubank, C. 1995. City of Modesto Urban Forestry Benefits. City of Modesto Parks and Recreation Department, Modesto, CA.

Gilstrap, C. 1999. Personal communication. Operations and Maintenance Department, City of Modesto, CA.

Hammer, T.T., R. Coughlin, and E. Horn. 1974. The effect of a large urban park on real estate value. J. Am. Inst. Plann. July:274-275.

Hofmann, A. 1998. Personal communication. Fresno Metropolitan Flood Control District, Fresno, CA.

Kimball, T. 1999. Personal communication. Electric Division, Modesto Irrigation District, Modesto, CA.

Lagarbo, A., and J. Brusca. 1996. Response to Survey on Street Tree Related Infrastructure Damage in
California Cities. U.S. Forest Service, Western Center for Urban Forest Research and Education, Davis, CA.

Marino, E. 1999. Personal communication. Supervisor, Modesto Urban Forestry Division, Modesto, CA.

McPherson, E.G., and R.A. Rowntree. 1989. Using structural measures to compare twenty-two U.S. street tree populations. Landscape J. 8:13-23.

McPherson, E.G., and J.R. Simpson. 1999. Carbon Dioxide Reduction Through Urban Forestry-Guidelines for Professional and Volunteer Tree Planters. General Technical Report PSW-171. U.S. Forest Service, Western Center for Urban Forest Research and Education, Davis, CA.

McPherson, E.G., J.R. Simpson, P.J. Peper, and Q. Xiao. 1999. Tree Guidelines for San Joaquin Valley Communities. Local Government Commission. Sacramento, CA.

McPherson, E.G., J.R. Simpson, and K.I. Scott. 1998 Estimating cost effectiveness of residential yard trees for improving air quality in Sacramento, California, using existing models. Atmos. Environ. 32:75-84.

Miller, R.W. 1997. Urban Forestry: Planning and Managing Urban Greenspaces. Prentice-Hall. Upper Saddle River, NJ.

More, T.A., T. Stevens, and P.G. Allen. 1988. Valuation of urban parks. Landscape Urban Plann. 15:139-152.

PG\&E.1998. Personal communication. Pacific Gas and Electric Company, Residential Services Department.

Peper, P.J., and E.G. McPherson. 1998. Comparison of five methods for estimating leaf area index of open-grown deciduous trees. J. Arboric. 24:98-111.

Peper, P.J., and S. Mori. Forthcoming. Growth estimates of street trees in Central California. U.S. Forest Service, Western Center for Urban Forest Research and Education, Davis, CA.

Pillsbury, N., J.L. Reimer, and R. Thompson. 1998. Tree volume equations for fifteen urban species in California. Urban Forest Ecosystems Institute, California Polytechnic State University, San Luis Obispo, CA.

Richards, N.A. 1982/83. Diversity and stability in a street tree population. Urb. Ecol. 7:159-171.

Rivera, J. 1998. Personal communication. Industrial Waste Supervisor, City of Modesto, CA.

Scott, K.I., E.G. McPherson, and J.R. Simpson. 1998. Air pollutant uptake by Sacramento's urban forest. J. Arboric. 24:224-234.

Schroeder, T. 1982. The relationship of local park and recreation services to residential property values. J. Leisure Res. 14:223-234.

Simpson, J.R. Forthcoming. Impact of street trees on residential energy use in Modesto, CA. U.S. Forest Service, Western Center for Urban Forest Research and Education, Davis, CA. 
Taha, H. 1996. Modeling impacts of increased urban vegetation on ozone air quality in the South Coast Air Basin. Atmos. Environ. 30:3423-3430.

U.S. Environmental Protection Agency. 1995. AP-42 Compilation of Air Pollutant Emission Factors (5th ed.). Volume I. U.S. Environmental Protection Agency, Research Triangle Park, NC.

Xiao, Q., E.G. McPherson, J.R. Simpson, and S.L. Ustin. 1998. Rainfall interception by Sacramento's urban forest. J. Arboric. 24:235-244.

Acknowledgments. This study was made possible by a grant from the City of Modesto Parks and Recreation Department. Additional funds were provided by the International Society of Arboriculture Research Trust (Duling Grant) and the Elvinia J. Slosson Fund. We are indebted to the following people in the City of Modesto who assisted with various aspects of this project: Patrick Foran, Peter Cowles, Chuck Gilstrap, Alan Lagarbo, Jeff Truesdail, Ernie Marino, Kevin Becker, John Brusca, John Rivera, Derald Weaver, Bob Cannell, and Tom Kimball (MID). Also assisting were Forest Service employees Giacamo Damonte, Stacy Kontrabecki, Todd Prager, Sabrina Mathis, Rosalie Venterea, and Klaus Scott. Use of trade or firm names in this paper does not imply endorsement by the U.S. Department of Agriculture of any product or service.

\section{${ }^{I *}$ Western Center for Urban Forest \\ Research and Education \\ USDA Forest Service, Pacific Southwest \\ Research Station \\ clo Department of Environmental Horticulture \\ University of California \\ Davis, CA 95616-8587}

\section{${ }^{2}$ Department of Land, Air, and Water Resources University of California \\ Davis, CA}

\section{*Corresponding author: E. Gregory McPherson}

Résumé. Cette étude permet de répondre à une question: "Est-ce que les bénéfices accrus retirés de la forêt urbaine de Modesto permettent de justifier un budget municipal annuel de 2 millions de dollars? ». Les résultats indiquent que les bénéfices qu'en retirent les résidants des 91179 arbres publics de Modesto excèdent les coûts de gestion par un facteur de 2. Au cours de l'année fiscale 1996-97, Modesto a dépensé 2,6 millions de dollars pour la foresterie urbaine dont $74 \%$ de ce montant était à l'entretien des arbres adultes. Les bénéfices annuels totaux de la forêt urbaine de Modesto étaient de 4,95 millions de dollars et les bénéfices nets de 2,3 millions. Le volume annuel de pollution captée a été de 154 tonnes métriques pour une valeur supposée de 1,48 millions de dollars, les bénéfices esthétiques et autres ont été estimés à une valeur de 1,5 millions de dollars, et les économies en énergie durant la saison estivale ont été de 0,87 millions de dollars. Il y a eu aussi d'autres bénéfices moindres découlant de la diminution du taux de ruissellement des eaux de surface et aussi de celui en dioxyde de carbone.

Zusammenfassung. Diese Studie beantwortet die Frage: Rechtfertigen die Vorzüge des Stadtwaldes von Modesto ein jährliches Budget in den öffentlichen Haushaltskassen von mehr als \$ 2 Millionen? Die Resultate deuten darauf hin, dals die Vorteile, welche die Anwohner von den ca. 91.179 öffentlichen Bäumen erhalten, die Managementkosten um das zweifache übersteigen. Im steuerlichen Zeitraum von 1997-98 gab die Stadt Modesto \$ 2.6 Millionen für urbane Forstwirtschaft aus, wobei $74 \%$ dieser Summe für die Pflege von am Standort etablierten Bäumen verwendet wurde. Die jährlichen Vorteile der Forstwirtschaft in Modesto betrugen im ganzen $\$ 4.95$ Millionen, d.h. die Nettovorzüge lagen bei $\$ 2.3$ Millionen. Die jährliche Aufnahme von Luftverunreinigungen betrug $154 \mathrm{t}$ mit einem Schätzwert von ca. $\$ 1.48$ Millionen, die ästhetischen und anderen Vorzüge hatten einen Schätzwert von ca. \$ 1.5 Millionen und die Energieeinsparungen während des Sommers betrugen $\$ 0.87$ Millionen. Darüberhinaus werden noch kleinere Vorzüge durch die Reduktion von Regenwasserabfluß und Kohlendioxidabgabe an die Atmosphäre genannt.

Resumen. Este estudio responde a la pregunta: ¿justifican los beneficios del bosque urbano de Modesto un presupuesto anual que excede los 2 millones de dólares? Los resultados indican que los beneficios que los residentes obtienen de los 91,179 árboles públicos de Modesto exceden los costos de mantenimiento por un factor de aproximadamente 2. En el año fiscal 1997-1998 Modesto gastó $\$ 2.6$ millones de dólares en dasonomía urbana y $74 \%$ de esta cantidad fue para el cuidado de árboles maduros. Los beneficios totales anuales del bosque urbano de Modesto fueron de $\$ 4.95$ millones y los beneficios netos fueron de $\$ 2.3$ millones. La reducción anual de la polución del aire fue de 154 toneladas métricas con un valor implicado de $\$ 1.48$ millones, la estética y otros beneficios tuvieron un valor estimado de $\$ 1.5$ millones, y los ahorros de energía en el verano tuvieron un valor de $\$ 0.87$ millones de dólares. Hubo beneficios más pequeños de reducciones en escorrentías y bióxido de carbón atmosférico. 